\author{
Н.Б. Аюшин, Е.П. Караулова, А.Е. Карлина, А.И. Чепкасова, \\ Т.Н. Слуцкая* \\ Тихоокеанский научно-исследовательский рыбохозяйственный центр, \\ 690091, г. Владивосток, пер. Шевченко, 4
}

\title{
ОТХОДЫ ПЕРЕРАБОТКИ ДАЛЬНЕВОСТОЧНЫХ ГОЛОТУРИЙ КАК СЫРЬЕ ДЛЯ ПОЛУЧЕНИЯ БИОЛОГИЧЕСКИ АКТИВНЫХ ДОБАВОК К ПИЩЕ
}

\begin{abstract}
Экспериментально установлены условия ферментативного гидролиза отходов, полученных при разделке промысловых голотурий, добываемых в морских акваториях российского Дальнего Востока. Показано, что гидролизаты содержат высокое количество тритерпеновых гликозидов, а также отличаются разнообразным составом макро- и микроэлементов, что позволяет позиционировать их как источник полезных минералов. Содержание селена настолько высоко, что 2-5 г лиофилизированного гидролизата фактически соответствуют рекомендованной суточной дозе этого элемента. Гидролизаты обладают высокой антиоксидантной активностью. Их органическая составляющая более чем на половину представлена биологически активными пептидами с молекулярной массой 2,5-5,0 кДа. Полученные результаты свидетельствуют о перспективности использования отходов переработки голотурий для получения биологически активных добавок широкого спектра действия.

Ключевые слова: голотурии, трепанг, кукумария, отходы, ферментативные гидролизаты, селен, тритерпеновые гликозиды, антиоксидантная активность, пептиды, БАД.

Ayushin N.B., Karaulova E.P., Karlina A.E., Chepkasova A.I., Slutskaya T.N. Wastes after processing of Far-Eastern holothurians as a raw material for production of biologically active supplements for food // Izv. TINRO. — 2016. — Vol. 186. - P. 238-246.

Conditions for enzymic hydrolysis of the wastes after processing of holothurians from the Far-Eastern Seas of Russia are determined experimentally. The hydrolyzates have high content of triterpene glycosides and a wide variety of inorganic compounds, so they could be considered as a source of useful minerals. The selenium content in $2-5 \mathrm{~g}$ of the lyophilized preparation corresponds to recommended daily consumption of this element for adult human. The hydrolyzates have high antioxidant activity. More than a half of their organic component is presented by biological active peptides by molecular mass $2.5-5.0 \mathrm{kDa}$. These results confirm the prospects of the holothurians waste using for production of multifunctional BASF.
\end{abstract}

* Аюшин Николай Буданович, кандидат биологических наук, старший научный сотрудник, е-mail: aidzen@yandex.ru; Караулова Екатерина Павловна, кандидат технических наук, стариий научный сотрудник, е-таil: karaulova2002@yandex.ru; Карлина Анастасия Евгеньевна, кандидат технических наук, старший научный сотрудник, е-таil: tinro@tinro.ru; Чепкасова Анна Ивановна, кандидат технических наук, научный сотрудник, e-mail: anna.chepkasova@, mail.ru; Слуикая Татьяна Ноевна, доктор технических наук, профессор, е-таil: tinro@tinro.ru.

Ayushin Nickolay B., Ph.D., senior researcher,e-mail: aidzen@yandex.ru; Karaulova Ekatherina P., Ph.D., senior researcher, e-mail: karaulova2002@yandex.ru; Karlina Anastasia E., Ph.D., senior researcher, e-mail: tinro@tinro.ru; ChepkasovaAnnaI.,Ph.D., researcher, e-mail: anna.chepkasova@, mail.ru; Slutskaya Tatiana N., D.Sc.,professor, e-mail: tinro@tinro.ru. 
Key words: holothurian, trepang, sea cucumber, waste, enzymatic hydrolysate, selenium, triterpene glycoside, antioxidant activity, peptide, BASF.

\section{Введение}

Дальневосточный трепанг считается одним из самых дорогих морских деликатесных продуктов. Несмотря на то что у побережья Китая обитает около 20 видов голотурий, в том числе и таких коммерчески важных, как Thelenota ananas, Actinopyga miliaris, Holothuria nobilis, дальневосточный трепанг Apostichopus japonicus ценится наиболее высоко и пользуется повышенным спросом в Китае, Республике Корея, Японии.

В целом дальневосточный трепанг содержит богатый набор биологически активных химических соединений, которые действуют раздельно или в комплексе, обусловливая высокую фармакологическую ценность получаемых из него продуктов (Левин, 2000; Аюшин и др., 2014). Среди этих веществ наиболее важны тритерпеновые гликозиды, по биологическому действию сходные с гликозидами женьшеня (Попов и др., 1994; Попов, 2002).

Другой объект, представляющий интерес как источник биологически активных веществ, - это кукумария японская Cucumariajaponica, запасы которой в дальневосточных морях значительны и промысел которой как пищевого продукта никогда не прекращался. Эта голотурия также содержит большое количество тритерпеновых гликозидов, лечебное действие которых несколько отличается от действия гликозидов трепанга (Калинин и др., 1994). Из японской кукумарии сотрудниками ТИНРО-центра был получен целый спектр биологически активных добавок к пище (Акулин и др., 2012).

Несмотря на то что голотурии с самого начала привлекали внимание исследователей прежде всего наличием тритерпеновых гликозидов, в последние годы вышло большое количество работ, посвященных веществам белковой природы этих животных. Так, был замечен заживляющий эффект пепсиновых гидролизатов коллагена дальневосточного трепанга, искусственно разводимого в Красном море (Park et al., 2012). Ферментативные гидролизаты атлантической голотурии Cucumaria frondosa проявляют ярко выраженную противовирусную активность (Tripoteau et al., 2015), успешно подавляя активность вируса герпеса. Пептиды, полученные с помощью обработки пепсином и пепсин-королазой РР мышечных тканей голотурии Isostichopus badionotus, обитающей в водах Мексиканского залива у берегов п-ова Юкатан, показали ACE-ингибиторную и радикал-связывающую активности, а также цитотоксический эффект против раковых клеток (Pérez-Vega et al., 2013). Все эти виды биологической активности проявляли пептиды с молекулярной массой в пределах 3000 Да. В народной медицине стран Восточной и Юго-Восточной Азии свойства продуктов деструкции мышечной ткани местных голотурий известны достаточно давно. Так, в Малайзии на о. Лангкави производится так называемая «Трепанговая вода» (Gamat Water), представляющая собой варочную воду, получаемую при обработке местных видов голотурий. Продукт позиционируется как общеукрепляющее средство, улучшающее аппетит и процесс кровообращения (http:/www.lelong.com.my/gel-gamat-water-based-karismaasli150942853-2015-06-Sale-P.htm).

При разделке трепанга и кукумарии в процессе производства кулинарного продукта или коммерческого полуфабриката образуются отходы - обрезки прианальных участков и венчиков с щупальцами вместе с небольшими (1-2 см) прирезями мышечной ткани, которые до настоящего времени нигде не используются. В то же время при проведении предварительных экспериментов установлено, что количество таких отходов для трепанга составляет от 4,2 до 5,8 \%, а для кукумарии - 6,8-7,0 \% к массе тела.

Исходя из изложенного выше целью работы являлось обоснование использования отходов от разделки голотурий для получения БАД широкого профиля действия.

\section{Материалы и методы}

В качестве объекта исследований были использованы отходы от разделки дальневосточного трепанга Apostichopus japonicus искусственного разведения (биотехнопарк 
«Заповедное», бухта Киевка, Японское море) и кукумарии японской Cucumariajaponica, добытой в зал. Петра Великого Японского моря.

Для гидролиза отходов использовались следующие ферментные препараты:

протамекс (Novozymes, Дания), протеолитическая активность - 400 ПЕ/г;

протосубтилин (ООО «Сиббиофарм», Россия), протеолитическая активность $120 \Pi \mathrm{\Pi E} / \Gamma ;$

целлолюкс А (ООО «Сиббиофарм», Россия), целлюлозолитическая активность - 2000 ЦЕ/г.

Температурные условия ферментолиза колебались между 45 и $50{ }^{\circ} \mathrm{C}$ согласно известным температурным оптимумам для этих ферментов. Несмотря на то что $\mathrm{pH}$ оптимумы используемых ферментов находятся в области от 5,0 до 7,5 реакцию проводили при рН субстрата 5,8-6,0 с целью исключения внесения в пищевую систему буферных растворов.

Общий химический состав мышечной ткани дальневосточного трепанга определяли в соответствии с ГОСТ 7636-85 «Рыба, морские млекопитающие, морские беспозвоночные, водоросли и продукты их переработки. Методы анализа».

Определение количества минеральных веществ проводили с помощью прокаливания навески пробы в муфельной печи при $400{ }^{\circ} \mathrm{C}$ до постоянного веса.

Элементный состав определяли на спектрофотометре «Нitachi» (Япония) с графитовой кюветой (мышьяк, кадмий, свинец) и пламенном спектрографе «Shimadzu 6880» после минерализации азотной кислотой.

Определение содержания общего азота проводили по методу Кьельдаля с использованием автоматического анализатора Kjeltec 2300 («Foss», Швеция).

Количество тритерпеновых гликозидов устанавливали спектрофотометрически, по методу Аминина (Аминин и др., 1981).

Определение количества аминосахаров проводили согласно ФС 42-1785-96, калибровочный график построен по глюкозамину.

Фракционный состав белков и пептидов анализировали с использованием жидкостного хроматографа (ВЭЖХ-системы) с применением насоса, детектора и колонки Superdex peptide $(1,0 \times 30,0 \mathrm{~cm})$, буфер 0,1 N NaCI - $20 \mathrm{mM}$ Tris-HCI $(\mathrm{pH} \mathrm{8,0)} \mathrm{при}$ скорости потока 0,5 мл/мин; обнаружение проводили при длине волны 280 нм.

Молекулярную массу белков и пептидов рассчитывали с помощью внешнего стандарта белков и пептидов (маркеров) разных молекулярных масс: карнозин (226 Да), бацитрацин (1422 Да), апротинин (6500 Да), цитохром (12500 Да), используя сравнение времени удерживания (Sigma-Aldrich).

Возможную биологическую активность определяли по уровню антиоксидантной активности полученных гидролизатов. Антиоксидантную активность ферментолизатов определяли двумя способами, основанными на взаимодействии исследуемого вещества с $\alpha$-дифенил- $\alpha$-пикрилгидразином (ДФПГ, фирма ICN, CША): по методу Глевинда (Владимиров, Арчаков, 1972) с использованием в качестве антиоксиданта сравнения дипептида карнозина и методу Парка и Мураками (Park et al., 2005), где мерой активности принимается $\mathrm{ES}_{50}$ - количество содержащегося в исследуемом веществе антиоксиданта, способного в два раза обесцветить 0,5 мМ раствора ДФПГ.

Для сравнения использовали БАД «Акмар» (ТУ 9283-353-00472012-2013).

\section{Результаты и их обсуждение}

Определено содержание воды, белка, липидов и минеральных веществ в мышечной ткани дальневосточного трепанга и кукумарии японской, а также в гомогенате отходов после разделки, т.е. в смеси прианальных участков и венчиков с щупальцами (табл. 1). Показано, что для отходов разделки трепанга и кукумарии характерно большее содержание минеральных веществ и меньшее - белка.

Известно, что белки мышечной ткани голотурий на 60-70 \% представлены коллагеном и плохо гидролизуются пищеварительными ферментами (Loewit, 1970; Иванкин 
Таблица 1

Общий химический состав мышечной ткани трепанга, кукумарии и отходов их переработки, \%

Table 1

General chemical composition of muscle tissues of trepang and sea cucumber and the wastes of their processing, $\%$

\begin{tabular}{|l|c|c|c|c|}
\hline \multirow{2}{*}{ Показатель } & \multicolumn{2}{c|}{ Трепанг } & \multicolumn{2}{c|}{ Кукумария } \\
\cline { 2 - 5 } & Мышечный мешок & Отходы & Мышечный мешок & Отходы \\
\hline Вода & $91,8 \pm 0,3$ & $91,0 \pm 0,3$ & $88,2 \pm 0,6$ & $86,7 \pm 0,5$ \\
\hline Липиды & $0,41 \pm 0,10$ & $0,38 \pm 0,20$ & $0,40 \pm 0,10$ & $0,70 \pm 0,20$ \\
\hline Белок & $4,4 \pm 0,5$ & $3,2 \pm 0,4$ & $8,6 \pm 0,6$ & $6,9 \pm 0,3$ \\
\hline Минеральные вещества & $3,2 \pm 0,1$ & $4,8 \pm 0,5$ & $2,8 \pm 0,2$ & $4,8 \pm 0,2$ \\
\hline
\end{tabular}

и др., 2001; Nagai et al., 2001), поэтому для достижения трепангом или кукумарией кулинарной готовности их варят в течение 2-3 ч.

Установлено, что такая длительная термическая обработка не позволяет полностью мацерировать отходы голотурий, поэтому принято решение применить ферментацию для дальнейшего получения из них БАД.

Поиски рациональных условий ферментативной деструкции отходов разделки голотурий проводили первоначально на примере щупалец кукумарии. Необходимо отметить, что применение ферментов микробиального происхождения не только снижает продолжительность гидролиза, но и в несколько раз увеличивает выход. В связи с доступностью и дешевизной для этой цели был выбран протамекс, обладающий более широким спектром действия по сравнению с другими препаратами, например с крабовым ферментным препаратом, разработанным в ТИНРО-центре (Козырева, Слуцкая, 1999; Тимчишина, 1999). В работе использовали установленное ранее (Чумак и др., 1995, 1996; Тимчишина, 1999) при производстве гидролизатов из мышечной ткани кукумарии соотношение фермент-субстратного комплекса и воды - $1: 1$. Данное соотношение является наиболее рациональным, так как увеличение количества воды снижает выход гликозидов и приводит к увеличению энергозатрат на единицу массы сырья, что уменьшает целесообразность производства.

С целью установления оптимального количества ферментного препарата (1002500 ПЕ/кг) и продолжительности гидролиза (1-4 ч), влияющих на количество тритерпеновых гликозидов (У, мкг/мл) в полученных продуктах, составлен и реализован план двухфазного эксперимента.

Минимальное и максимальное количество фермента устанавливали учитывая данные ранее проведенных работ по получению гидролизатов из мышечной ткани кукумарии (Пат. № 2095000).

На основании реализации полного факторного эксперимента ПФЭ $2^{2}$ рассчитаны коэффициенты и составлены уравнения регрессии, по которым найдены оптимальные условия гидролиза венчиков и щупалец кукумарии (табл. 2).

Таблица 2

Расчет оптимальных условий гидролиза щупалец кукумарии (фермент — протамекс)

Calculation of optimal conditions for hydrolysis of the sea cucumber tentacles

Table 2 with Protamex enzyme

\begin{tabular}{|c|c|c|c|c|}
\hline № уровня & Количество фермента $\left(\mathrm{x}_{1}\right)$, ПЕ/кг & Время гидролиза $\left(\mathrm{x}_{2}\right)$, ч & $\mathrm{Y}_{\text {расч}}$, мкг/мЛ & $\mathrm{У}_{\text {экпп }}$, мкг/мЛ \\
\hline 0 & 1300 & 2,50 & 1245,1 & 1261,3 \\
\hline 1 & 1660 & 2,97 & 1517,4 & 1528,6 \\
\hline 2 & 2020 & 3,44 & 1854,6 & 1843,6 \\
\hline 3 & 2380 & 3,90 & 2256,9 & 2279,1 \\
\hline
\end{tabular}

Увеличение количества протамекса до 2380 ПЕ/кг и времени гидролиза хотя и приводит к увеличению содержания гликозидов, но сопровождается появлением горького вкуса в продукте, что является весомой причиной для исключения данного варианта как неприемлемого по органолептическим показателям. Определение аминного азота 
показало, что горький вкус появляется при превышении содержания его более 400 мг/100 г продукта. Поэтому оптимальными условиями при ферментолизе отходов от разделки кукумарии приняты следующие: время 3,5 ч; количество фермента 2000 ПЕ/кг; рН 6,5; гидромодуль $1: 1$; температура $50 \pm 5^{\circ} \mathrm{C}$.

Для получения гидролизатов из щупалец, венчиков и внутренностей трепанга использовался протамекс и другая протеаза бактериального происхождения - протосубтилин. Кроме того, было решено использовать гидролазу целлолюкс, разрушающую трехмерные полисахариды некрахмалистого типа, поскольку известно, что многие белки мышечной ткани трепанга являются протеогликанами, а мягкие ткани содержат липополисахариды (Himaya et al., 2010).

При использовании ферментов гидролиз проводили в одинаковых условиях, а именно: вносили фермент с дозировкой 2000 ед. активности на 1 кг измельченного сырья и проводили процесс при температуре $45{ }^{\circ} \mathrm{C}$ в течение 3,5 ч с гидромодулем $1: 1$ при постоянном перемешивании. Далее инактивировали фермент нагреванием реакционной смеси до $80{ }^{\circ} \mathrm{C}$ в течение 10 мин и фильтровали, полученный фильтрат лиофилизировали. Выход сухого продукта составил 11,5-13,0 \% от массы сырья. Химический состав гидролизатов, а также БАД «Акмар» из варочных вод трепанга представлен в табл. 3.

Таблица 3

Химический состав ферментативных гидролизатов из отходов разделки дальневосточного трепанга и БАД «Акмар», \%

Table 3

Chemical composition of enzymic hydrolysates from the wastes of trepang processing and BASF «Akmar», \%

\begin{tabular}{|c|c|c|c|c|c|}
\hline \multicolumn{2}{|c|}{ Лиофилизированный препарат } & $\begin{array}{c}\text { Белково-пептидный } \\
\text { материал }\end{array}$ & Липиды & Вода & $\begin{array}{c}\text { Минеральные } \\
\text { вещества }\end{array}$ \\
\hline \multicolumn{2}{|l|}{ БАД «Акмар» } & 42,2 & \multirow{4}{*}{ Следы } & \multirow{4}{*}{$3-5$} & 52,5 \\
\hline \multirow{3}{*}{ Отходы, гидролизованные } & целлолюксом & 23,5 & & & 69,8 \\
\hline & протамексом & 24,1 & & & 72,3 \\
\hline & протосубтилином & 22,0 & & & 73,1 \\
\hline
\end{tabular}

Из представленных данных видно, что содержание веществ белково-пептидной природы во всех трех гидролизатах почти одинаково и в два раза ниже, чем в БАД «Акмар», а содержание минеральных веществ значительно выше.

Поскольку биологическая активность продукции из трепанга в первую очередь определяется наличием в ней тритерпеновых гликозидов, в полученных гидролизатах и некоторых других препаратах, изготовленных из той же партии трепанга, было определено их содержание, а также содержание аминосахаров, известных своей биологической активностью.

Согласно полученным данным (табл. 4) гидролизаты мало отличаются по содержанию гликозидов от БАД «Акмар». То же относится и к содержанию аминосахаров, за исключением варианта с применением целлолюкса, где их содержание более чем в 2 раза выше.

Таблица 4

Содержание тритерпеновых гликозидов и аминосахаров в продукции из трепанга, мг/г

Content of triterpene glycosides and amino sugars in productions of trepang, $\mathrm{mg} / \mathrm{g}$

\begin{tabular}{|c|c|c|c|}
\hline \multicolumn{2}{|l|}{ Образец } & Гликозиды & Аминосахара \\
\hline \multicolumn{2}{|l|}{ Трепанг сыромороженый } & 2,2 & 0,84 \\
\hline \multicolumn{2}{|l|}{ БАД «Акмар» } & 270,0 & 4,64 \\
\hline \multirow{3}{*}{ Отходы, гидролизованные } & протосубтилином & 224,2 & 4,71 \\
\hline & протамексом & 279,0 & 4,28 \\
\hline & целлолюксом & 214,3 & 10,22 \\
\hline
\end{tabular}


Поскольку в полученных гидролизатах весьма значительна доля минеральных веществ, был исследован их элементный состав (табл. 5).

Таблица 5

Содержание макро- и микроэлементов в лиофилизированных гидролизатах из отходов трепанга, мкг/г

Content of macro- and microelements in lyophilized hydrolysates from the wastes of trepang processing, $\mu \mathrm{g} / \mathrm{g}$

\begin{tabular}{|l|c|c|c|c|c|c|c|c|c|c|c|c|}
\hline \multicolumn{1}{|c|}{ Препарат } & $\mathrm{As}$ & $\mathrm{Cd}$ & $\mathrm{Pb}$ & $\mathrm{Cu}$ & $\mathrm{Zn}$ & $\mathrm{Mn}$ & $\mathrm{Ca}$ & $\mathrm{Mg}$ & $\mathrm{Na}$ & $\mathrm{K}$ & $\mathrm{Fe}$ & $\mathrm{Se}$ \\
\hline $\begin{array}{l}\text { Гидролизат с } \\
\text { протосубтилином }\end{array}$ & 0,15 & 0,05 & 2,64 & 7,48 & 67,52 & 61,55 & 2257,00 & 843,46 & 656,50 & 5086,45 & 957,94 & 10,05 \\
\hline $\begin{array}{l}\text { Гидролизат с } \\
\text { протамексом }\end{array}$ & 0,12 & 0,05 & 2,75 & 8,66 & 56,50 & 66,33 & 2665,35 & 722,44 & 555,12 & 4293,31 & 827,36 & 8,27 \\
\hline $\begin{array}{l}\text { Гидролизат с } \\
\text { целлолюксом }\end{array}$ & 0,17 & 0,10 & 3,41 & 9,88 & 72,58 & 81,58 & 2504,03 & 739,92 & 580,85 & 4407,25 & 846,77 & 6,86 \\
\hline БАД «Акмар» & - & 0,06 & - & 1,83 & 6,75 & - & 9271,80 & 426,50 & \multicolumn{2}{|c|}{ Не опр. } & 162,50 & 0,83 \\
\hline Норма, не более* & 0,4 & 2 & 10 & 30 & 200 & - & - & - & - & - & - & - \\
\hline
\end{tabular}

* Допускается в соответствии с требованиями ТР ТС 021/2011.

Как видно из представленных данных, полученные гидролизаты гораздо более богаты микроэлементами, чем БАД «Акмар», при этом ни в одном случае не наблюдается недопустимых концентраций токсичных элементов. Значительно большое содержание в БАД «Акмар» кальция объясняется наличием в мышечном мешке трепанга известковых спикул, которых в щупальцах и прианальных участках нет. Привлекает внимание значительное содержание в гидролизатах селена - эссенциального элемента, в малых дозах необходимого для нормального развития животных и растений, а также для обеспечения здоровья и профилактики болезней у человека (Лукьянова и др., 2006). Суточная норма селена в питании для человека составляет 20-70 мкг, максимально допускается 350-400 мкг.

Исследование распределения молекулярных масс пептидных компонентов полученных гидролизатов и для сравнения БАД «Акмар» выявило следующее. Для всех трех гидролизатов установлено подобие распределения хроматографических зон (пиков), а также близкое количество пептидов с молекулярной массой 2,5-5,0 кДа (табл. 6-8). Так, для гидролизатов, полученных с помощью целлолюкса, это количество составляет 52,8, протамекса $-59,5$ и протосубтилина - 60,8 \%.

Таблица 6

Распределение молекулярных масс белково-пептидной фракции отходов переработки трепанга, гидролизованных целлолюксом

Distribution of molecular masses for protein-peptide fraction of the trepang wastes hydrolyzed by Celloluxe

\begin{tabular}{|c|c|c|c|}
\hline Пик & Объем, мл & Доля от общего количества, \% & Молекулярная масса, Да \\
\hline 1 & 1,89 & 0,01 & 12569,6 \\
\hline 2 & 7,56 & 5,62 & 9898,2 \\
\hline 3 & 18,40 & 26,62 & 4791,0 \\
\hline 4 & 21,15 & 26,24 & 3495,3 \\
\hline 5 & 23,96 & 4,98 & 2171,4 \\
\hline 6 & 27,64 & 25,24 & 437,6 \\
\hline 7 & 36,01 & 10,63 & $<300$ \\
\hline
\end{tabular}

При исследовании БАД «Акмар» (табл. 9) превалирующей являлась фракция 5,5 кДа (59,1 \% общего количества).

При этом антиоксидантная активность (табл. 10) всех четырех препаратов различается незначительно, в 2,5-3,0 раза превышая активность антиоксиданта средней силы, а именно дипептида карнозина, что объясняется высоким количеством пептидов с молекулярной массой 2,5-5,0 кДа. Это не противоречит ранее 
Таблица 7

Распределение молекулярных масс белково-пептидной фракции отходов переработки трепанга, гидролизованных протамексом

Table 7

Distribution of molecular masses for protein-peptide fraction of the trepang wastes hydrolyzed by Protomex

\begin{tabular}{|c|c|c|c|}
\hline Пик & Объем, мл & Доля от общего количества, $\%$ & Молекулярная масса, Да \\
\hline 1 & 0,58 & 0,24 & 13186,8 \\
\hline 2 & 0,94 & 0,04 & 13017,2 \\
\hline 3 & 1,10 & 0,03 & 12941,8 \\
\hline 4 & 1,28 & 0,02 & 12857,0 \\
\hline 5 & 7,41 & 1,43 & 9968,9 \\
\hline 6 & 8,40 & 0,03 & 9502,4 \\
\hline 7 & 14,09 & 0,09 & 6821,6 \\
\hline 8 & 18,31 & 24,28 & 4833,4 \\
\hline 9 & 21,01 & 20,66 & 3561,3 \\
\hline 10 & 22,18 & 14,58 & 3010,0 \\
\hline 11 & 24,52 & 2,26 & 1907,6 \\
\hline 12 & 27,51 & 19,90 & 498,8 \\
\hline 13 & 30,0 & 10,70 & $<300,0$ \\
\hline 14 & 36,04 & 5,04 & $<300,0$ \\
\hline
\end{tabular}

Таблица 8

Распределение молекулярных масс белково-пептидной фракции отходов переработки трепанга, гидролизованных протосубтилином

Table 8

Distribution of molecular masses for protein-peptide fraction of the trepang wastes hydrolyzed by Protosubtiline

\begin{tabular}{|c|c|c|c|}
\hline Пик & Объем, мл & Доля от общего количества, \% & Молекулярная масса, Да \\
\hline 1 & 7,53 & 1,00 & 9912,3 \\
\hline 2 & 18,42 & 22,42 & 4781,5 \\
\hline 3 & 21,15 & 21,50 & 3495,3 \\
\hline 4 & 22,12 & 16,87 & 3038,3 \\
\hline 5 & 24,48 & 1,92 & 1926,4 \\
\hline 6 & 27,51 & 18,07 & 498,8 \\
\hline 7 & 29,83 & 11,88 & $<300,0$ \\
\hline 8 & 35,74 & 5,78 & $<300,0$ \\
\hline
\end{tabular}

Распределение молекулярных масс белково-пептидной фракции БАД «Акмар»

Таблица 9

Distribution of molecular masses for protein-peptide fraction of BASF «Akmar»

\begin{tabular}{|c|c|c|c|}
\hline Пик & Объем, мл & Доля от общего количества, \% & Молекулярная масса, Да \\
\hline 1 & 7,67 & 23,59 & 9846,37 \\
\hline 2 & 16,92 & 59,12 & 5488,27 \\
\hline 3 & 20,62 & 9,74 & 3745,03 \\
\hline 4 & 22,12 & 5,70 & 3038,31 \\
\hline 5 & 26,12 & 0,06 & 1153,72 \\
\hline 6 & 26,33 & 0,03 & 1054,78 \\
\hline 7 & 27,59 & 0,34 & 461,14 \\
\hline 8 & 35,77 & 0,03 & $<300,0$ \\
\hline
\end{tabular}

полученным данным по антирадикальной активности низкомолекулярных пептидов (Караулова и др., 2015).

\section{Выводы}

Экспериментально установлены условия гидролиза отходов, полученных при разделке голотурий. Показано, что гидролизаты содержат высокое количество глико- 
Антиоксидантная активность лиофилизированных ферментативных гидролизатов из отходов переработки трепанга

Table 10

Antioxidant activity of freeze-dried enzymic hydrolysates from the wastes of trepang processing

\begin{tabular}{|l|c|c|}
\hline \multicolumn{1}{|c|}{ Препарат } & $\begin{array}{c}\text { По методу Глевинда, } \\
\text { мГ карнозина/мг пробы }\end{array}$ & $\begin{array}{c}\text { По методу Парк, Мураками, } \\
\mathrm{ES}_{50}\end{array}$ \\
\hline Гидролизат с протосубтилином & 2,8 & 5,45 \\
\hline Гидролизат с протамексом & 2,8 & 5,55 \\
\hline Гидролизат с целлолюксом & 2,5 & 4,55 \\
\hline БАД «Акмар» & 2,6 & 4,81 \\
\hline
\end{tabular}

зидов, отличаются разнообразным составом макро- и микроэлементов, что позволяет дополнительно позиционировать их как источник полезных минералов. Содержание селена настолько высоко, что 2-5 г лиофилизированного гидролизата фактически соответствуют рекомендованной суточной дозе этого элемента. Высокая антиоксидантная активность гидролизатов из голотурий, возможно, объясняется тем, что их органическая часть почти на $60 \%$ представлена биологически активными пептидами с молекулярной массой около 2,5-5,0 кДа; можно отметить тенденцию увеличения антирадикальной активности в связи с увеличением количества этих пептидов.

Полученные результаты свидетельствуют о перспективности использования отходов переработки голотурий для получения биологически активных добавок многообразного спектра действия.

\section{Список литературы}

Акулин В.Н., Павель К.Г., Слуцкая Т.Н. и др. Эффективность биологически активных добавок из голотурий и совершенствование способов их получения // Изв. ТИНРО. - 2012. — Т. 170. - С. 291-298.

Аминин Д.Л., Шевцова Е.Б., Анисимов М.М., Кузнецова Т.А. Спектрофотометрическое определение стихопозида А из голотурии Stichopus japonicus S. // Антибиотики. - 1981. - T. 26. - № 8. - С. 585-588.

Аюшин Н.Б., Ким А.Г., Слуцкая Т.Н. Химический состав и содержание биологически активных веществ в мышечной ткани трепанга Stichopus japonicus // Изв. вузов. Сер. Пищевая технология. - 2014. - Т. 176. - С. 35-38.

Владимиров Ю.А., Арчаков А.И. Перекисное окисление липидов в биологических мембранах : моногр. - М., 1972. — 252 с.

Иванкин А.И., Неклюдов А.Д., Кудряшов Л.С. и др. Влияние коллагеназной активности фермента из гепатопанкреаса крабов на биохимическое состояние объектов животного происхождения // Хранение и переработка сельхозсырья. — 2001. - № 1. - С. 28-32.

Калинин В.И., Левин В.С., Стоник В.А. Химическая морфология: тритерпеновые гликозиды голотурий (Holothurioidea, Echinodermata) : моногр. - Владивосток : Дальнаука, 1994. - 284 c.

Караулова Е.П., Чепкасова А.И., Слуцкая Т.Н. и др. Антирадикальный эффект низкомолекулярных пептидов экстрактов и гидролизатов тканей водных гидробионтов // Изв. ТИНРО. - 2015. - Т. 182. - С. 269-276.

Козырева О.Б., Слуцкая Т.Н. Обоснование условий протеолиза покровных тканей головоногих моллюсков с целью получения пищевых эмульсий // Изв. ТИНРО. — 1999. — Т. 125. - C. 338-343.

Левин В.С. Дальневосточный трепанг. Биология, промысел, воспроизводство : моногр. - СПб. : Голанд, 2000. - 200 c.

Лукьянова О.Н., Ковековдова Л.Т., Струппуль Н.Э., Иваненко Н.В. Селен в морских организмах : моногр. - Владивосток : ТИНРО-центр, 2006. - 152 с.

Попов А.М. Сравнительное изучение цитотоксического и гемолитического действия тритерпеноидов женьшеня и голотурий // Изв. РАН. Сер. биол. — 2002. — № 2. — С. 155-164.

Попов А.М., Агафонова Л.Н., Самошина Н.Ф., Уварова Н.И. Изучение иммуномодулирующей активности тетрациклических гликозидов даммаранового и голостанового ряда // Антибиотики и химиотерапия. - 1994. - Т. 39, № 7. — С. 24-29. 
Тимчишина Г.Н. Обоснование технологий получения пищевых добавок из кукумарии (Cucumaria japonica) на основе комплексного использования сырья : автореф. дис. ... канд. техн. наук. - Владивосток, 1999. - 24 с.

Чумак А.Д., Павель К.Г., Тимчишина Г.Н. Способ получения гидролизатов из кукумарии // Тез. докл. науч. конф. «Рыбохозяйственные исследования океана». - Владивосток, 1996. - C. 31-32.

Чумак А.Д., Тимчишина Г.Н., Павель К.Г. Способ получения гидролизатов из кукумарии // Тез. докл. Междунар. конф. «Проблемы качества потребительских товаров и коммерческой деятельности в условиях рынка». - Владивосток : ДВКИ, 1995. - С. 31-32.

Himaya S.W.A., Ryu BoMi, Qian Zhong-Ji, Kim Se-Kwon. Sea cucumber, Stichopus japonicus ethyl acetate fraction modulates the lipopolysaccharide induced iNOS and COX-2 via MAPK signaling pathway in murine macrophages // Environmental Toxicology and Pharmacology. - 2010. - Vol. 30, Iss. 1. - P. 68-75.

Loewit K. Untersuchung and Forsch // Lebensmittel. — 1970. — Bd. 1. — S. 143.

Nagai T., Yamashita E., Taniguchi K. et al. Isolation and characterisation of collagen from the outer skin waste material of cuttlefish // Food Chem. - 2001. - Vol. 72. — P. 425-429.

Park E.Y., Murakami H., Mori T., Matsumura Y. Effect of protein and peptide addition in lipid oxidation in powder model system // J. Agric. Food. Chem. - 2005. — Vol. 53. - P. 137-144.

Park Soo-Yeong, Lim Hee Kyoung, Lee Seogjae et al. Pepsin-solubilised collagen (PSC) from Red Sea cucumber (Stichopus japonicus) regulates cell cycle and the fibronectin synthesis in HaCaT cell migration // Food Chemistry. — 2012. - Vol. 132, Iss. 1. — P. 487-492.

Pérez-Vega J.A., Olivera-Castillo L., Gómez-Ruiz J.A., Hernández-Ledesma B. Release of multifunctional peptides by gastrointestinal digestion of sea cucumber (Isostichopus badionotus) // Journ. of Functional Foods. - 2013. - Vol. 5, Iss. 2. - P. 869-877.

Tripoteau L., Bedoux G., Gagnon J., Bourgougnon N. In vitro antiviral activities of enzymatic hydrolysates extracted from byproducts of the Atlantic holothurian Cucumaria frondosa // Process Biochemistry. — 2015. - Vol. 50, Iss. 5. - P. 867-875.

Поступила в редакичию 25.05.16 г. 